\title{
Methanoculleus hydrogenitrophicus sp. nov., a methanogenic archaeon isolated from wetland soil
}

Correspondence

Xiuzhu Dong

dongxz@im.ac.cn
Jianqing Tian, ${ }^{1,2}$ Yanfen Wang ${ }^{1}$ and Xiuzhu Dong ${ }^{2}$

\author{
${ }^{1}$ Graduate University, Chinese Academy of Sciences, Beijing 100049, PR China \\ ${ }^{2}$ State Key Laboratory of Microbial Resources, Institute of Microbiology, Chinese Academy of \\ Sciences, Beijing 100101, PR China
}

Natural wetlands are an important methane source inhabited by abundant methanogenic archaea (Matthews \& Fung, 1987). Our previous study showed a wide diversity of methanogens in the Zoige wetland of the Tibetan plateau (Zhang et al., 2008b), and phylogenetic analyses based on both $16 \mathrm{~S}$ rRNA and mcrA gene sequences indicated that methanogens of the families Methanosarcinaceae and Methanomicrobiales were prevalent in the Zoige wetland. Furthermore, a novel psychrophilic, methylotrophic member of the Methanosarcinaceae, 'Methanolobus psychrophilus', was isolated and described (Zhang et al., 2008a). Other studies have shown that members of the Methanomicrobiales are likely to be the prevalent hydrogenotrophic methanogens in cold wetlands (Ganzert et al., 2007; Grabowski et al., 2005), and many uncultured members of the Methanomicrobiales were enriched by using low levels of $\mathrm{H}_{2}$ (Sakai et al., 2007). These studies together imply that members of the Methanomicrobiales seemed to predominate under low $\mathrm{H}_{2}$, as found in situ in wetlands. In this work, by constructing an artificial butyrate-degrading consortium to create an environment with a low level of $\mathrm{H}_{2}$, we isolated a novel strain of the Methanomicrobiales from Zoige wetland soil.

The GenBank/EMBL/DDBJ accession number for the $16 \mathrm{~S}$ rRNA gene sequence of strain $\mathrm{HC}^{\top}$ is FJ977567.

Graphs showing effects of temperature, $\mathrm{pH}$ and $\mathrm{NaCl}$ on growth of strain $\mathrm{HC}^{\top}$ are available as supplementary material with the online version of this paper.
'Syntrophomonas erecta subsp. sporosyntropha' JCM 13344 was preserved in our laboratory and cultivated in a medium containing $20 \mathrm{mM}$ crotonate (Wu et al., 2006). Methanoculleus chikugoensis DSM $13459^{\mathrm{T}}$, Methanoculleus marisnigri DSM $1498^{\mathrm{T}}$, Methanoculleus submarinus DSM $15122^{\mathrm{T}}$ and Methanoculleus thermophilus DSM $2373^{\mathrm{T}}$ were purchased from the Deutsche Sammlung von Mikroorganismen und Zellkulturen (DSMZ; Braunschweig, Germany) and cultivated under a gas phase of $1.01 \times 10^{5}$ $\mathrm{Pa} \mathrm{H}_{2} / \mathrm{CO}_{2}(80: 20)$. The sampling site, the Zoige wetland, is located on the Tibetan plateau ( $\left.33^{\circ} 56^{\prime} \mathrm{N} 102^{\circ} 52^{\prime} \mathrm{E}\right)$. The soil, covered by growth of Carex muliensis, was collected at the depth of 20-30 cm at the end of May 2007 and placed in sterile serum bottles sealed with butyl rubber stoppers and kept in a cool box during transportation.

The basal medium used in this study was prepared as described previously (Ma et al., 2005). The medium was dispensed into screw-capped tubes sealed with butyl rubber stoppers, with a headspace of $1.01 \times 10^{5} \mathrm{~Pa} \mathrm{H}_{2} / \mathrm{CO}_{2}$ $(80: 20)$ or $\mathrm{N}_{2}$ for routine cultivation, as indicated. To isolate low $\mathrm{H}_{2}$-preferring methanogens from the soil, $0.5 \mathrm{ml}$ each of soil slurry and pre-grown culture of ' $S$. erecta subsp. sporosyntropha' JCM 13344 were inoculated into $5 \mathrm{ml}$ medium with $20 \mathrm{mM}$ butyrate as sole carbon source and incubated anaerobically at $37{ }^{\circ} \mathrm{C}$. Butyrate degradation and methane production were monitored by gas chromatography as described previously (Ma et al., 2005; Wu et al., 2006). A butyrate-degrading consortium 
was obtained by subculturing the enrichment in the same medium for eight to ten transfers, and the enrichment was then serial diluted in basal medium with $\mathrm{H}_{2} / \mathrm{CO}_{2}(80: 20)$ as headspace; $0.5 \mathrm{~g}$ vancomycin $\mathrm{l}^{-1}$ (final concentration) was added to inhibit bacterial growth (Kotelnikova et al., 1998). After several subcultures in $\mathrm{H}_{2} / \mathrm{CO}_{2} \quad(80: 20)$ medium, cultivation was performed by the Hungate rolltube technique (Hungate, 1969) and the purified strain $\mathrm{HC}^{\mathrm{T}}$ was obtained from a single colony in a Hungate tube. Strain $\mathrm{HC}^{\mathrm{T}}$ was further purified by repeated culture in roll tubes. The purity of the strain was confirmed by light microscope examination, the absence of growth in rich medium such as peptone/yeast extract/glucose (PYG) broth and identity of $16 \mathrm{~S}$ rRNA gene sequences in a generated clone library. The bacteria-specific primer $27 \mathrm{~F}$ [5'-AGAGTTTGATC(AC)TGGCTCAG-3'], the archaeaspecific primer Arch4F (5'-TCCGGTTGATCCTGCCRG$\left.3^{\prime}\right)$ and the prokaryotic universal primer $1492 \mathrm{R}\left(5^{\prime}\right.$ GGTTACCTTGTTACGACTT-3') were used to amplify the $16 \mathrm{~S}$ rRNA gene.

Cell morphology of strain $\mathrm{HC}^{\mathrm{T}}$ was examined under a light microscope (BH-2; Olympus) and transmission electron microscope (H-600A; Hitachi). Before observation, cells were coated with palladium/iridium alloy by using a highvacuum evaporator (HUS-5GB; Hitachi). Cells were negatively stained with uranyl acetate and lead citrate according to Reynolds (1963). Cell motility was observed by phase-contrast microscopy (BH-2; Olympus) by following the method of Boone \& Whitman (1988) and Ma et al. (2005). Both examinations showed that cells of strain $\mathrm{HC}^{\mathrm{T}}$ were irregular coccoids, around $0.8-2 \mu \mathrm{m}$ in diameter (Fig. 1), and not motile. Cells stained Gramnegative and resisted disruption by $1 \%$ SDS (w/v) or hypotonic solution, tested as described by Boone \& Whitman (1988). Strain $\mathrm{HC}^{\mathrm{T}}$ grew strictly anaerobically; growth was inhibited completely in the presence of air.

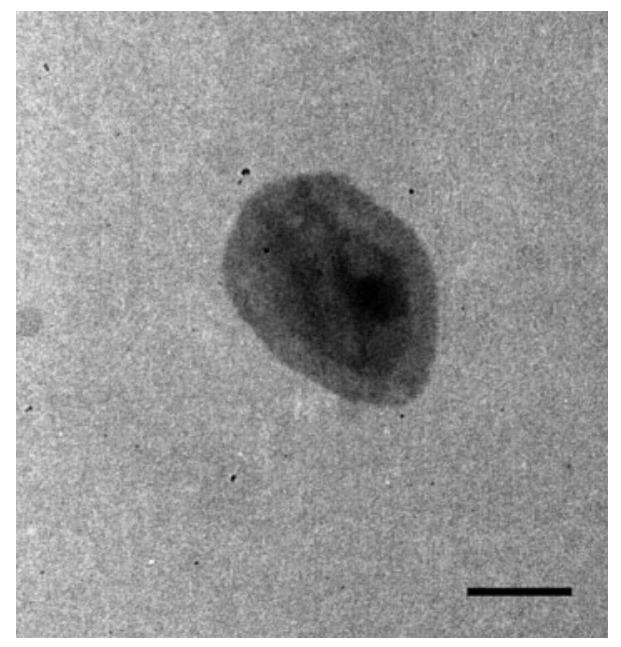

Fig. 1. Electron micrograph of a cell of strain $\mathrm{HC}^{\top}$. Bar, $0.5 \mu \mathrm{m}$.
Growth and substrate utilization were determined by monitoring the $\mathrm{OD}_{600}$ and methane production. All inoculations and transfers were done with syringes and needles, and incubations for growth/substrate utilization tests were performed in triplicate at $37{ }^{\circ} \mathrm{C}$ for over 35 days. Basal medium containing $0.2 \%$ yeast extract was used for growth tests. The temperature profile of strain $\mathrm{HC}^{\mathrm{T}}$ was determined in $\mathrm{H}_{2} / \mathrm{CO}_{2}(80: 20)$ medium in a water bath with a temperature gradient from 8 to $55{ }^{\circ} \mathrm{C}$ at $1{ }^{\circ} \mathrm{C}$ intervals. Growth of strain $\mathrm{HC}^{\mathrm{T}}$ was observed at $18-45^{\circ} \mathrm{C}$, with optimum growth at $37{ }^{\circ} \mathrm{C}$. To determine the $\mathrm{pH}$ range for growth, $\mathrm{H}_{2} / \mathrm{CO}_{2}(80: 20)$ medium was adjusted to $\mathrm{pH}$ 3.0-9.0 with $1 \mathrm{M} \mathrm{HCl}$ or $\mathrm{NaOH}$; growth was observed at $\mathrm{pH}$ 5.0-8.5, with optimum growth around $\mathrm{pH}$ 6.6. According to the method of Lai et al. (2000) and Boone \& Whitman (1988), the specific growth rate of strain $\mathrm{HC}^{\mathrm{T}}$ during exponential growth was determined as $0.031 \mathrm{~h}^{-1}$ when grown in $\mathrm{H}_{2} / \mathrm{CO}_{2}(80: 20)$ medium at $37{ }^{\circ} \mathrm{C}$ and $\mathrm{pH}$ 6.6, calculated by linear regression of the logarithm of the total amount of methane accumulated. The salinity range was determined in media with $0.05-0.5 \mathrm{M} \mathrm{NaCl}$; optimum growth was observed with around $0.2 \mathrm{M} \mathrm{NaCl}$. Effects of temperature, $\mathrm{pH}$ and $\mathrm{NaCl}$ concentration on growth of strain $\mathrm{HC}^{\mathrm{T}}$ are shown in Supplementary Fig. S1, available in IJSEM Online.

The substrate spectrum of strain $\mathrm{HC}^{\mathrm{T}}$ was determined by addition of each carbon source to the basal medium and then determining methane production after incubation at $37{ }^{\circ} \mathrm{C}$ for 35 days. It was determined that $\mathrm{H}_{2} / \mathrm{CO}_{2}$ was the only substrate that supported growth and methane production; formate, acetate, methanol, ethanol, trimethylamine, isobutanol and 2-propanol (each at $20 \mathrm{mM}$ ) did not. Requirements for growth factors were determined by measuring growth in the $\mathrm{H}_{2} / \mathrm{CO}_{2}$ medium and omitting one of the components in each test, including vitamins, yeast extract, peptone and acetate. Strain $\mathrm{HC}^{\mathrm{T}}$ grew poorly without peptone and vitamins. Yeast extract $(0.1-2.5 \%)$ was not necessary but stimulated growth.

DNA extraction was carried out as described previously (Ma et al., 2005). The $\mathrm{G}+\mathrm{C}$ content was determined using the thermal denaturation method (Marmur \& Doty, 1962; Owen \& Pitcher, 1985) using DNA from Escherichia coli K12 as a reference; the $\mathrm{G}+\mathrm{C}$ content of genomic DNA of strain $\mathrm{HC}^{\mathrm{T}}$ was determined to be $60.2 \mathrm{~mol} \%$.

PCR amplification and sequencing of the 16S rRNA gene were performed as described previously ( $\mathrm{Ma}$ et al., 2005) using primers Arch4F and 1492R (Furlong et al., 2002). The 16S rRNA gene of strain $\mathrm{HC}^{\mathrm{T}}$ was sequenced by SinoGenoMax Company (Beijing, China) and the sequence was submitted to GenBank to search for similar sequences using the BLAST algorithm. The best matching sequences were retrieved from the database and aligned and similarity analysis was performed using CLUSTAL_X (Thompson et al., 1994). Based on a consensus length of $1378 \mathrm{bp}$ of the $16 \mathrm{~S}$ rRNA gene sequence, a phylogenetic tree (Fig. 2) rooted with Methanomicrobium mobile DSM $1539^{\mathrm{T}}$ and 


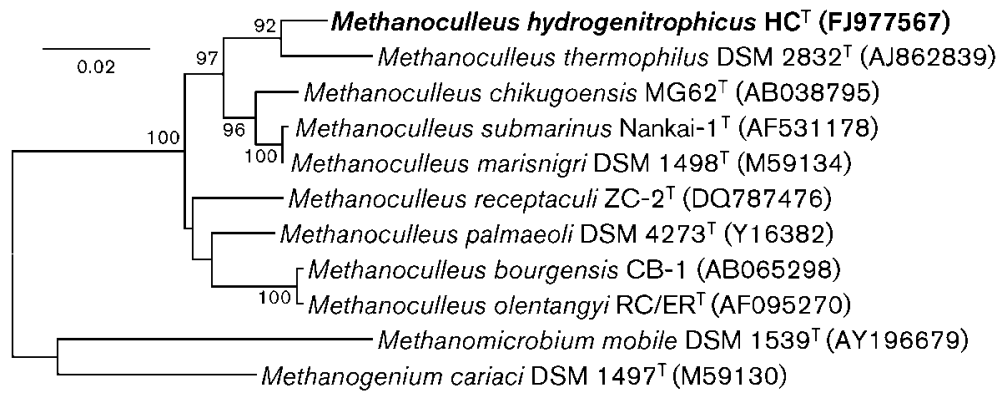

Fig. 2. Phylogenetic tree showing the position of strain $\mathrm{HC}^{\top}$ among species of the genus of Methanoculleus. Based on a consensus length of $1378 \mathrm{bp}$ of $16 \mathrm{~S}$ rRNA gene sequences, the tree was constructed by the neighbour-joining method and rooted with Methanomicrobium mobile DSM $1539^{\top}$ and Methanogenium cariaci DSM $1497^{\top}$. The stability of the tree topology was estimated by bootstrap analysis based on 1000 replications. Numbers at branch points are percentages of bootstrap support. Accession numbers are shown in parentheses. Bar, $2 \%$ sequence divergence.
Methanogenium cariaci DSM $1497^{\mathrm{T}}$ was constructed using neighbour-joining method implemented in the program MEGA4 (Tamura et al., 2007). The robustness of the tree was evaluated by bootstrap analysis (Felsenstein, 1985) with 1000 resamplings. Phylogenetic analysis showed that strain $\mathrm{HC}^{\mathrm{T}}$ and type strains of other species of Methanoculleus displayed 16S rRNA gene sequence similarities of 94.8$97.2 \%$, indicating that it could represent a novel species of this genus.

DNA-DNA relatedness was determined based on the initial reassociation rate according to the method of Owen \& Pitcher (1985) at $61-65{ }^{\circ} \mathrm{C}$ by using a UV800 spectrophotometer (Beckman). The DNA-DNA relatedness between strain $\mathrm{HC}^{\mathrm{T}}$ and its phylogenetic relatives Methanoculleus chikugoensis DSM $13459^{\mathrm{T}}$, Methanoculleus marisnigri DSM $1498^{\mathrm{T}}$, Methanoculleus submarinus DSM $15122^{\mathrm{T}}$ and Methanoculleus thermophilus DSM $2373^{\mathrm{T}}$ was determined to be $42.0,39.8,23.5$ and $45.7 \%$, respectively; these values are lower than the threshold of $70 \%$ DNA-DNA hybridization recommended for species delineation.

On the basis of phenotypic and phylogenetic characteristics, strain $\mathrm{HC}^{\mathrm{T}}$ was determined to belong to the genus Methanoculleus. However, some phenotypic features distinguished strain $\mathrm{HC}^{\mathrm{T}}$ from the other species listed in Table 1. The major phenotypic differences were as follows: (i) strain $\mathrm{HC}^{\mathrm{T}}$ differed from all members of the genus Methanoculleus by using $\mathrm{H}_{2} / \mathrm{CO}_{2}$ only as the substrate for growth and methane production; (ii) acetate did not support growth of strain $\mathrm{HC}^{\mathrm{T}}$ nor was it required, while acetate was a growth factor for other members of the genus; (iii) the optimum $\mathrm{NaCl}$ concentration for growth differed between strain $\mathrm{HC}^{\mathrm{T}}$ and Methanoculleus bourgensis (Asakawa \& Nagaoka, 2003); (iv) the optimum $\mathrm{pH}$ and temperature for growth of strain $\mathrm{HC}^{\mathrm{T}}$ were distinct from

Table 1. Differential characteristics between strain $\mathrm{HC}^{\top}$ and type strains of phylogenetically related Methanoculleus species

Strains: 1, HC ${ }^{\mathrm{T}}$; 2, Methanoculleus thermophilus DSM 2373 ${ }^{\mathrm{T}}$ (unless indicated, data from Rivard \& Smith, 1982; Spring et al., 2005); 3, Methanoculleus submarinus DSM 15122 $2^{\mathrm{T}}$ (Mikucki et al., 2003); 4, Methanoculleus marisnigri DSM 1498 ${ }^{\mathrm{T}}$ (Maestrojuán et al., 1990); 5, Methanoculleus chikugoensis DSM $13459^{\mathrm{T}}$ (Dianou et al., 2001). All strains stain Gram-negative and use $\mathrm{H}_{2} / \mathrm{CO}_{2}$ as a substrate for growth and methane production (verified for reference strains in this study).

\begin{tabular}{|c|c|c|c|c|c|}
\hline Characteristic & 1 & 2 & 3 & 4 & 5 \\
\hline Cell morphology ${ }^{\star}$ & IC & IC & IC & C & IC \\
\hline DNA G + C content $(\mathrm{mol} \%)$ & $60.2 \pm 1.2$ & 59.1 & 58 & $61.7 \pm 1$ & 62.2 \\
\hline Optimum & $\sim 37$ & $55 \dagger$ & $45 \dagger$ & $\sim 40 \dagger$ & $25-30 \dagger$ \\
\hline Range & $18-45$ & $37-65 \dagger$ & $10-55 \dagger$ & $18-60 \dagger$ & $15-40 \dagger$ \\
\hline Optimum pH & $\sim 6.6$ & 7 & $4.8-7.7$ & $7-8$ & $6.7-7.2$ \\
\hline Formate & - & $+\dagger$ & $+\dagger$ & $+\dagger$ & $+\dagger$ \\
\hline Secondary alcohols & - & - & + & + & + \\
\hline \multicolumn{6}{|l|}{ Growth factor required } \\
\hline Yeast extract & - & $-\dagger$ & $-\dagger$ & $+\dagger$ & $-\dagger$ \\
\hline Acetate & - & $+\dagger$ & $+\dagger$ & $+\dagger$ & $+\dagger$ \\
\hline Optimum $\mathrm{NaCl}$ concentration (M) & 0.2 & 0.2 & 0.2 & 0.2 & 0.1 \\
\hline
\end{tabular}

${ }^{\star} \mathrm{C}$, Coccoid; IC, irregular coccoid.

$\dagger$ Data obtained in this study. 
those of Methanoculleus receptaculi (Cheng et al., 2008) and Methanoculleus oldenburgensis (Asakawa \& Nagaoka, 2003).

According to the minimal standards for the description of new taxa of methanogens (Boone \& Whitman, 1988; Stackebrandt \& Goebel, 1994) and based on phylogenetic and phenotypic characteristics, a novel species of the genus Methanoculleus, Methanoculleus hydrogenitrophicus sp. nov., is proposed.

\section{Description of Methanoculleus hydrogenitrophicus sp. nov.}

Methanoculleus hydrogenitrophicus [hy.dro.ge.ni.tro'phi. cus. N.L. n. hydrogenum hydrogen (from Gr. n. hudôr water; Gr. v. gennaô to produce); N.L. masc. adj. trophicus nursing, tending or feeding (from Gr. adj. trophikos); N.L. masc. adj. hydrogenitrophicus using hydrogen as electron donor].

Cells are non-motile, Gram-negative-staining, irregular coccoids. Cells resist lysis by $1 \%$ (w/v) SDS. Produces methane only from $\mathrm{H}_{2}$ and $\mathrm{CO}_{2}$. Acetate is not required for growth; yeast extract stimulates growth. Growth occurs at $18-45{ }^{\circ} \mathrm{C}$ with optimum growth around $37{ }^{\circ} \mathrm{C}$. The $\mathrm{pH}$ range is $5.0-8.5$, with optimum growth around $\mathrm{pH}$ 6.6. The DNA G + C content of the type strain is $60.2 \mathrm{~mol} \%$.

The type strain, $\mathrm{HC}^{\mathrm{T}}\left(=\mathrm{CGMCC} 1.5146^{\mathrm{T}}=\mathrm{JCM} 16311^{\mathrm{T}}\right)$, was isolated from the Zoige wetland, China.

\section{Acknowledgements}

This work was supported by grants from the National Nature Science Foundation $(30830007,30621005)$ and a Knowledge Innovation grant of the Chinese Academy of Sciences (kzcx2-yw-418-03).

\section{References}

Asakawa, S. \& Nagaoka, K. (2003). Methanoculleus bourgensis, Methanoculleus olentangyi and Methanoculleus oldenburgensis are subjective synonyms. Int J Syst Evol Microbiol 53, 1551-1552.

Boone, D. R. \& Whitman, W. B. (1988). Proposal of minimal standards for describing new taxa of methanogenic bacteria. Int J Syst Bacteriol 38, 212-219.

Cheng, L., Qiu, T., Li, X., Wang, W., Deng, Y., Yin, X. \& Zhang, H. (2008). Isolation and characterization of Methanoculleus receptaculi sp. nov. from Shengli oil field, China. FEMS Microbiol Lett 285, 6571.

Dianou, D., Miyaki, T., Asakawa, S., Morii, H., Nagaoka, K., Oyaizu, H. \& Matsumoto, S. (2001). Methanoculleus chikugoensis sp. nov., a novel methanogenic archaeon isolated from paddy field soil in Japan, and DNA-DNA hybridization among Methanoculleus species. Int J Syst Evol Microbiol 51, 1663-1669.

Felsenstein, J. (1985). Confidence limits on phylogenies: an approach using the bootstrap. Evolution 39, 783-791.

Furlong, M. A., Singleton, D. R., Coleman, D. C. \& Whitman, W. B. (2002). Molecular and culture-based analyses of prokaryotic communities from an agricultural soil and the burrows and casts of the earthworm Lumbricus rubellus. Appl Environ Microbiol 68, 12651279.
Ganzert, L., Jurgens, G., Munster, U. \& Wagner, D. (2007). Methanogenic communities in permafrost-affected soils of the Laptev Sea coast, Siberian Arctic, characterized by 16 SRNA gene fingerprints. FEMS Microbiol Ecol 59, 476-488.

Grabowski, A., Nercessian, O., Fayolle, F., Blanchet, D. \& Jeanthon, C. (2005). Microbial diversity in production waters of a lowtemperature biodegraded oil reservoir. FEMS Microbiol Ecol 54, 427-443.

Hungate, R. E. (1969). A roll tube method for cultivation of strict anaerobes. Methods Microbiol 3B, 117-132.

Kotelnikova, S., Macario, A. J. L. \& Pedersen, K. (1998), Methanobacterium subterraneum sp. nov., a new alkaliphilic, eurythermic and halotolerant methanogen isolated from deep granitic groundwater. Int J Syst Bacteriol 48, 357-367.

Lai, M.-C., Shu, C.-M., Chen, S.-C., Lai, L.-J., Chiou, M.-S. \& Hua, J.-J. (2000). Methanosarcina mazei strain O1M9704, methanogen with novel tubule isolated from estuarine environment. Curr Microbiol 41, 15-20.

Ma, K., Liu, X. \& Dong, X. (2005). Methanobacterium beijingense sp. nov., a novel methanogen isolated from anaerobic digesters. Int $J$ Syst Evol Microbiol 55, 325-329.

Maestrojuán, G. M., Boone, D. R., Xun, L., Mah, R. A. \& Zhang, L. (1990). Transfer of Methanogenium bourgense, Methanogenium marisnigri, Methanogenium olentangyi, and Methanogenium thermophilicum to the genus Methanoculleus gen. nov., emendation of Methanoculleus marisnigri and Methanogenium, and description of new strains of Methanoculleus bourgense and Methanoculleus marisnigri. Int J Syst Bacteriol 40, 117-122.

Marmur, J. \& Doty, P. (1962). Determination of the base composition of deoxyribonucleic acid from its thermal denaturation temperature. J Mol Biol 5, 109-118.

Matthews, E. \& Fung, I. (1987). Methane emission from natural wetlands: global distribution, area, and environmental characteristics of sources. Global Biogeochem Cycles 1, 61-86.

Mikucki, J. A., Liu, Y., Delwiche, M., Colwell, F. S. \& Boone, D. R. (2003). Isolation of a methanogen from deep marine sediments that contain methane hydrates, and description of Methanoculleus submarinus sp. nov. Appl Environ Microbiol 69, 3311-3316.

Owen, R. J. \& Pitcher, D. (1985). Current methods for estimating DNA base composition and levels of DNA-DNA hybridization. In Chemical Methods in Bacterial Systematics, pp. 67-93. Edited by M. Goodfellow \& D. E. Minnikin. London: Academic Press.

Reynolds, E. S. (1963). The use of lead citrate at high $\mathrm{pH}$ as an electron opaque stain in electron microscopy. J Cell Biol 17, 208-212.

Rivard, C. J. \& Smith, P. H. (1982). Isolation and characterization of a thermophilic marine methanogenic bacterium, Methanogenium thermophilicum sp. nov. Int J Syst Bacteriol 32, 430-436.

Sakai, S., Imachi, H., Sekiguchi, Y., Ohashi, A., Harada, H. \& Kamagata, Y. (2007). Isolation of key methanogens for global methane emission from rice paddy fields: a novel isolate affiliated with the clone cluster Rice Cluster I. Appl Environ Microbiol 73, 4326-4331.

Spring, S., Schumann, P. \& Spröer, C. (2005). Methanogenium frittonii Harris et al. 1996 is a later synonym of Methanoculleus thermophilus (Rivard and Smith 1982) Maestrojuán et al. 1990. Int J Syst Evol Microbiol 55, 1097-1099.

Stackebrandt, E. \& Goebel, B. M. (1994). Taxonomic note: a place for DNA-DNA reassociation and $16 \mathrm{~S}$ rRNA sequence analysis in the present species definition in bacteriology. Int J Syst Bacteriol 44, 846849.

Tamura, K., Dudley, J., Nei, M. \& Kumar, S. (2007). MEGA4: molecular evolutionary genetics analysis (MEGA) software version 4.0. Mol Biol Evol 24, 1596-1599. 
Thompson, J. D., Higgins, D. G. \& Gibson, T. J. (1994). ClustaL W: improving the sensitivity of progressive multiple sequence alignment through sequence weighting, position-specific gap penalties and weight matrix choice. Nucleic Acids Res 22, 4673-4680.

Wu, C., Liu, X. \& Dong, X. (2006). Syntrophomonas erecta subsp. sporosyntropha subsp. nov., a spore-forming bacterium that degrades short chain fatty acids in co-culture with methanogens. Syst Appl Microbiol 29, 457-462.
Zhang, G., Jiang, N., Liu, X. \& Dong, X. (2008a). Methanogenesis from methanol at low temperatures by a novel psychrophilic methanogen, "Methanolobus psychrophilus" sp. nov., prevalent in Zoige wetland of the Tibetan plateau. Appl Environ Microbiol 74, 6114-6120.

Zhang, G., Tian, J., Jiang, N., Guo, X., Wang, Y. \& Dong, X. (2008b). Methanogen community in Zoige wetland of Tibetan plateau and phenotypic characterization of a dominant uncultured methanogen cluster ZC-I. Environ Microbiol 10, 1850-1860. 